\title{
ANALISIS DAN PERANCANGAN SISTEM PENDUKUNG KEPUTUSAN PENERIMA BANTUAN PROGRAM KELUARGA HARAPAN DENGAN SIMPLE ADDITIVE WEIGHTING (SAW) PADA DINAS SOSIAL, KEPENDUDUKAN DAN PENCATATAN SIPIL PROVINSI JAMBI
}

\author{
$\underline{\text { Fadhliazis }^{1}, \text { Sarjono }^{2}}$ \\ Program Studi Magister Sistem Informasi, Pasca Sarjana STIKOM Dinamika Bangsa, Jambi \\ Email: faaiz84@gmail.com ${ }^{1}$, sarjono@gmail.com ${ }^{2}$
}

\begin{abstract}
There are so many programe is given by goverment to tackle proverty. One of them is Program Keluarga Harapan (PKH). But, data of beneficiery receiver is not suitable yet as something that hope. The reason is not optimal act of determining status. Although, beneficiery receiver is not on target. Application prototype planner system to support final decision for PKH beneficiery receiver is used to take decision is Simple Addictive Weighting System (SAW). It wears Use Case Diagram, Activity Diagram, and Class Diagram as model of system planner. Which is result assessment is done by system. That have two measurment, proper or not proper. SAW Method is choosen because of this method can determine quality grade each atribute. Then, continue with rank process will do to select best alternative from a lot of alternatives. Such as; poor family which is include proper category based on some criterias is defineted. With that rank process, assesment will be appropriate because based on criteria grade and quality grade that determine alternative. It will get proper result. The result will be come holder for Social, Population, and Civil Registration department in Jambi Province. The assesment can be used to measure poor family that proper to get PKH beneficiery. Which is this data will be given to the Ministry of Social Services of Indonesia Republic later. It become proper data for goverment to give the PKH beneficiery is on the target.
\end{abstract}

Keywords: Program Keluarga Harapan (PKH), Design, Prototype, Decision Support System (DSS), Simple Additive Weighting (SAW)

\begin{abstract}
Abstrak
Beberapa program pemerintah Pusat dalam upaya penanggulangan kemiskinan telah banyak dilakukan diantaranya melalui Program Keluarga Harapan (PKH), tetapi data calon penerima bantuan belum sesuai dengan apa yang diharapkan, Salah satu sebab adalah karena penentuan status layak dan tidak layak sebagai penerima bantuan belum optimal sehingga dalam memberikan bantuan PKH belum tepat sasaran.

Perancangan aplikasi prototype Sistem Pendukung Keputusan penerima bantuan PKH yang digunakan dalam menentukan keputusan adalah metode Simple Additive Weighting (SAW) dengan menggunakan Use Case Diagram, Activity Diagram dan Class Diagram sebagai model perancangan sistem. Dimana hasil penilaian yang dilakukan oleh sistem diberikan status kelayakan yaitu Layak dan Tidak Layak. Metode SAW dipilih karena dapat menentukan nilai bobot untuk setiap atribut, kemudian dilanjutkan dengan proses rangking yang akan menyeleksi alternative terbaik dari sejumlah alternatif yaitu keluarga miskin yang dikategorikan layak berdasarkan kriteria-kriteria yang di tentukan. Dengan proses rangking tersebut, penilaian akan lebih tepat karena didasarkan pada nilai kriteria dan bobot yang sudah ditentukan sehingga akan mendapatkan hasil yang tepat terhadap keluarga miskin yang layak mendapatkan bantuan PKH. Hasil tersebut menjadi dasar bagi Dinas Sosial Kependudukan dan Pencatatan Sipil Provinsi Jambi untuk menentukan keluarga miskin yang berhak mendapatkan bantuan PKH dimana data ini nantinya diserahkan ke Kementerian Sosial Republik
\end{abstract}


Indonesia menjadi data layak yang mendapat bantuan dari pemerintah sehingga bantuan tersebut tepat sasaran.

Kata Kunci : Program Keluarga Harapan (PKH), Perancangan, Prototype, Sistem Pendukung Keputusan (SPK), Simple Additive Weighting (SAW)

\section{(C) 2019 Jurnal Manajemen Sistem Informasi}

\section{Pendahuluan}

Program Keluarga Harapan (PKH) merupakan program perlindungan sosial dari pemerintah pusat melalui pemberian bantuan tunai bersyarat kepada Rumah Tangga Sangat Miskin (RTSM)/Keluarga Sangat Miskin (KSM) yang ditetapkan sebagai keluarga penerima manfaat PKH sesuai dengan syarat dan ketentuan. Tujuan program ini dalam jangka pendek diharapkan mampu membantu RTSM/KSM mengurangi beban pengeluaran. Pada jangka menengah diharapkan mampu menciptakan perubahan perilaku peserta dalam mengakses layanan kesehatan dan pendidikan sehingga menghasilkan generasi yang lebih sehat dan cerdas dan dalam jangka panjang PKH diharapkan dapat memutus rantai kemiskinan antar generasi. Program semacam ini secara internasional dikenal sebagai Conditional Cash Transfers (CCT) atau Bantuan Tunai Bersyarat. Pengalaman dari negara-negara lain yang telah menjalankan program serupa menunjukan bahwa program ini terbukti memberikan manfaat positif, terutama bagi keluarga dengan tingkat kemiskinan paling bawah.

Pada tahun 2007 Pemerintah Indonesia melaksanakan Program Keluarga Harapan di 7 provinsi dengan jumlah sasaran penerima program sebanyak 500.000 RTSM/KSM. Ketujuh provinsi tersebut adalah: Sumatera Barat, DKI Jakarta, Jawa Barat, Jawa Timur, Sulawesi Utara, Gorontalo, dan Nusa Tenggara Timur. Berbeda dengan Bantuan Langsung Tunai, bantuan bersyarat ini diberikan kepada keluarga yang memenuhi persyaratan dan ketentuan tertentu. Sasaran penerima PKH adalah anggota RTSM/KSM yang memiliki ibu hamil/baru melahirkan, anak balita, anak usia sekolah terutama SD, SMP, SMA, lanjut usia di atas 70 tahun dan penyandang disabilitas berat. Penerima bantuan ini adalah ibu atau wanita yang mengurus anak pada rumah tangga yang bersangkutan. Namun bila tidak ada ibu,bibi, nenek atau kakak perempuan dapat menjadi penerima bantuan. Kewajiban yang harus dilakukan oleh penerima bantuan bidang kesehatan yaitu bagi ibu hamil dan balita yang harus memeriksakan kesehatannya secara rutin tiap bulan di fasilitas kesehatan terdekat (puskesmas, pustu, poskesdes, posyandu dan lain-lain). Sedangkan untuk peserta didik diwajibkan untuk memenuhi absensi minimal $85 \%$ dari hari efektif sekolah setiap bulannya. Khusus anggota keluarga peserta PKH penyandang disabilitas berat dan lanjut usia, kewajibannya di sesuaikan dengan kondisinya.

Program Keluarga Harapan (PKH) dilaksanakan di Provinsi Jambi tahun 2012 dengan Kota Jambi sebagai pilot project nya dengan jumlah sasaran peserta penerima PKH nya adalah 3.689 RTSM/KSM. Oleh karena itu Pemerintah Pusat melalui Kementerian Sosial membentuk Pelaksana Program Keluarga Harapan (PPKH) untuk melaksanakan Program Keluarga Harapan (PKH) di Kabupaten Kota di bawah Dinas Sosial masingmasing wilayah.

Tantangan utama dalam menjalankan program penanggulangan kemiskinan adalah mengidentifikasi secara tepat sasaran yang akan menerima manfaat suatu program. Ketepatan memilih sasaran memiliki dampak langsung kepada keberhasilan pencapaian tujuan program perlindungan sosial dalam menanggulangi kemiskinan. Sumber data peserta penerima PKH adalah data dari Pendataan Program Perlindungan Sosial (PPLS) yang telah diselesaikan oleh BPS (Badan Pusat Statistik) tahun 2011 dan diolah oleh Tim Nasional Percepatan Penanggulangan Kemiskinan (TNP2K ) menjadi Basis Data Terpadu untuk Program Perlindungan Sosial dan diserahkan ke Kementerian Sosial Republik Indonesia untuk digunakan untuk menjalankan program-program penanggulangan kemiskinan dalam Data Terpadu Penanganan Fakir Miskin. Data keluarga miskin calon peserta yang diterima dari Kementerian Sosial RI di Provinsi Jambi untuk penerima bantuan PKH berupa file softcopy pdf terdiri dari surat undangan pertemuan awal, data awal calon penerima PKH dan formulir validasi. Surat undangan pertemuan awal ini di serahkan kepada calon penerima bantuan untuk dapat menghadiri pertemuan awal di tempat yang sudah ditentukan dengan terlebih dahulu berkoordinasi dengan perangkat desa/kelurahan/kecamatan. Koordinasi ini diperlukan untuk mengetahui dari awal siapa saja dari daftar calon penerima bantuan yang sudah mampu, pindah dan alamat tidak ditemukan. Calon penerima bantuan yang datang di wajibkan membawa dokumen kependudukan dan dokumen lain seperti Kartu Keluarga, KTP, Kartu Keluarga Sejahtera, Buku Raport anak, Kartu kunjungan Ibu Hamil dll. Pada saat di validasi oleh Pendamping Sosial PKH menggunakan ceklist formulir validasi terkait persyaratan untuk mendapat bantuan PKH berdasarkan kelengkapan berkas diantaranya kartu keluarga, dan proses tanya 
jawab ada beberapa calon penerima bantuan yang tidak memenuhi kriteria tersebut, disebabkan oleh calon penerima bantuan tidak lagi memiliki komponen yang menjadi persyaratan. Data hasil ceklist form validasi yang sudah di validasi yang sesuai menjadi data valid dan data yang tidak sesuai ceklist form validasi menjadi data tidak layak, kemudian data tersebut dikirimkan ke Kementerian Sosial untuk dipersiapkan data bayar bagi data yang valid. Data warga masyarakat miskin calon penerima bantuan PKH dari Kementerian Sosial yang di validasi oleh petugas sosial masih terdapat kekurangan karena data PPLS 2011 dari Badan Pusat Statistik masih menggunakan data lama yang belum diperbaharui dan juga teknik survey dimana ada satu upaya menanyakan ke perangkat desa/lurah setempat sebelum turun kelapangan sehingga tidak langsung bertatap muka dengan masyarakat miskin yang di data, teknik ini berpotensi kurang tepat sehingga menghasilkan data penerima bantuan tidak valid karena pendataan bersifat subjektif, dan pada saat di cek oleh petugas terjadi Inclusion Error yaitu calon peserta penerima PKH yang tidak layak menerima bantuan masuk dalam data, Serta juga terjadi Exclusion Error yaitu warga yang seharusnya layak menerima PKH tidak masuk dalam data sehingga banyak masyarakat miskin yang seharusnya tersentuh oleh bantuan tersebut tidak mendapatkan apa yang menjadi hak nya dan penerima program bantuan menjadi tidak tepat sasaran.

Oleh karena itu diusulkan proses penentuan penerima bantuan PKH dengan melakukan pendataan oleh pendamping sosial yang sudah tersebar di provinsi Jambi berdasarkan ketentuan persyaratan yang telah ditetapkan untuk menjadi data baru valid untuk penerima bantuan PKH. Dimana hasil pendataan ini nantinya akan diproses melalui sistem terkomputerisasi dengan menggunakan Sstem Pendukung Keputusan sehingga menghasilkan keputusan yang tepat dan objektif kemudaian data ini di usulkan ke Kementerian Sosial menjadi data valid yang layak menerima bantuan. Metoda yang digunakan yaitu metoda Simple Additive Weighting (SAW) yaitu merupakan metode yang menggunakan penjumlahan terbobot dengan rating pada setiap alternatif. Yogiek Indra Kurniawan (2015) Simple Additive Weighting (SAW) merupakan proses pembobotan yang sering juga dikenal sebagai metode penjumlahan terbobot. Konsep dasar dari $S A W$ adalah untuk menemukan proses penjumlahan terbobot dari masing-masing alternatif pada semua kriteria. Metode ini digunakan karena mampu menyeleksi alternatif terbaik dari sejumlah alternatife yang akan digunakan dalam penentuan calon penerima PKH berdasarkan kriteria-kriteria yang ditentukan.

Berdasarkan uraian yang dikemukakan atas, maka diusulkan solusi dalam bentuk tesis dengan mengangkat judul "Analisis dan Perancangan Sistim Pendukung Keputusan Penerima Bantuan Program Keluarga Harapan dengan Simple Additive Weighting ( $S A W$ ) Pada Dinas Sosial, Kependudukan dan Pencatatan Sipil Provinsi Jambi”.

\section{Tinjauan Pustaka}

Ada beberapa penelitian terdahulu yang digunakan oleh penulis sebagai rujukan yang relevan terkait dengan judul penelitian yang sedang diangkat yaitu "Analisis dan Perancangan Sistim Pendukung Keputusan Penerima Bantuan Program Keluarga Harapan dengan Simple Additive Weighting ( SAW) Pada Dinas Sosial , Kependudukan dan Pencatatan Sipil Provinsi Jambi.

a. Sistem Pendukung Keputusan Klasifikasi Keluarga Miskin Menggunakan Metode Simple Additve Weighting (SAW) Sebagai Acuan Penerima Bantuan Dana Pemerintah (Studi Kasus: Pemerintah Desa Taman Martani, Sleman) :

Penelitian yang dilakukan oleh Uning Lestari dan Muhammad Targiono yang berjudul Sistem Pendukung KeputusanKlasifikasi Keluarga Miskin Menggunakan Metode Simple Additve Weighting (SAW) Sebagai Acuan Penerima Bantuan Dana Pemerintah (Studi Kasus: Pemerintah Desa Taman Martani, Sleman). Penerima bantuan dana pemerintah di desa Taman Martani Sleman belum tepat sasaran dikarenakan belum ada klasifikasi keluarga miskin yang menerima bantuan. Dari penelitian yang dilakukan dapat menghasilan sebuah aplikasi Sistem Pendukung Keputusan Penentuan Keluaga Miskin yang dapat membantu Tim Penanggulangan Kemiskinan (UPT TPK) dalam menentukan status kemiskinan suatu keluarga, sehingga dalam proses penanggulangan kemiskinan khususnya penyaluran bantuan dana untuk warga miskin dari pemerintah, bantuan tersebut dapat diberikan kepada warga yang benar-benar membutuhkan sehingga penylauran bantuan dapat tepat sasaran. Penelitian yang penulis lakukan memiliki perbedaan dibandingkan dengan penelitian tersebut diatas. Faktor pembedadari penelitian tersebut pada lokasi penelitian dan implementasi, dimana studi kasus diambil dari lokasi yang berbeda, dimana peneliti sebelumya di Desa Taman Martani Sleman. Sedangkan pada penelitian ini bertempat di Dinas Sosial Kependudukan dan Pencatatan Sipil Provinsi Jambi dan sebatas rancangan prototype.

b. SistemPendukung Keputusan Pemberian Bantuan Masyarakat Miskin Menggunakan Metode Simple Additive Weighting (SAW): 
Penelitian yang dilakukan oleh Desriyanti dan Muslim yang berjudul Sistem Pendukuung Keputusan Pemberian Bantuan Masyarakat Miskin Menggunakan Metode Simple Additive Weighting (SAW).Siapa yang layak menerima bantuan dari pemerintah di desa Cekok Kecamatan Babadan Ponorogo belum ada karena penenuan layak dan tidak layak menerima bantuan tidak ada. Dari penelitian yang dilakukan dapat menghasilan sebuah prototypeaplikasi Sistem Pendukung Keputusan Bantuan Miskin yang dapat mempermudah pengambilan keputusan pada desa khususnya masalah penentuan pemberi bantuan bagi masyarakat desa Cekok dengan aplikasi sistem. Penelitian yang penulis lakukan memiliki perbedaan dibandingkan dengan penelitian tersebut diatas. Faktor pembeda dari penelitian tersebut pada lokasi penelitian, dimana studi kasus diambil dari lokasi yang berbeda, dimana peneliti sebelumya di Desa Cekok Kecamatan Babadan Ponorogo. Sedangkan pada penelitian sekarang ini bertempat di Dinas Sosial Kependudukan dan Pencatatan Sipil Provinsi Jambi.

c. Sistem Penunjang Keputusan Penerima Bantuan Desa Di Kecamatan Klungkung Dengan Metode SAW. Penelitian yang dilakukan oleh Ni Kadek Sukerti yang berjudul Sistem Penunjang Keputusan Penerima Bantuan Desa di Kecamatan Klungkung dengan Metode Simple Additive Weighting (SAW).Belum adanya sistem yang akan merekomendasikan untuk pengambilan keputusan dalam menentukan desa yang berhak menerima bantuan berupa barang bersyarat dari pemerintah. Dari penelitian yang dilakukan menghasilan sebuah Sistem Pendukung Keputusan yang berguna bagi para pengambil eputusan dala menentukan desa yang berhak menerima bantuan berupa barang bersyarat dari pemerintah. Penelitian yang penulis lakukan memiliki perbedaan dibandingkan dengan penelitian tersebut diatas. Faktor pembeda dari penelitian tersebut pada lokasi penelitian, dimana studi kasus diambil dari lokasi yang berbeda, dimana peneliti sebelumya di Kecamatan Klungkung. Sedangkan pada penelitian sekarang ini bertempat di Dinas Sosial Kependudukan dan Pencatatan Sipil Provinsi Jambi.

\section{Metodologi}

Alur dalam proses penyelesaian penelitian ini pada dasarnya merupakan urutan langkah-langkah yang harus dilakukan oleh peneliti sehingga hasilkan suatu sasaran akhir dari penelitian ini, yaitu menghasilkan sebuah sistem penunjang keputusan penerima bantuan PKH. Adapun alur penelitian ini adalah sebagai berikut :

\subsection{Alur Penelitian}

Alur dalam proses penyelesaian penelitian ini pada dasarnya merupakan urutan langkah-langkah yang harus dilakukan oleh peneliti sehingga hasilkan suatu sasaran akhir dari penelitian ini, yaitu menghasilkan sebuah sistem penunjang keputusan penerima bantuan PKH. Adapun alur penelitian ini adalah sebagai berikut :

$\underline{\text { Alur Penelitian }}$

$\underline{\text { Keluaran }}$

\begin{tabular}{|c|c|}
\hline Perumusan Masalah & Masalah yang di bahas \\
\hline Studi Literatur & $\begin{array}{l}\text { Pemahaman teori dan konsep tentang } \\
\text { masalah penelitian }\end{array}$ \\
\hline Pengumpulan Data & $\begin{array}{l}\text { Data- data yang diperlukan dalam } \\
\text { penelitian }\end{array}$ \\
\hline Analisis Sistem & $\begin{array}{l}\text { Menganalisis sistem yang berjalan } \\
\text { dan analisis kebutuhan sistem }\end{array}$ \\
\hline Perancangan Sistem & $\begin{array}{l}\text { Pembuatan SPK dengan Simple } \\
\text { Additive Weighting } \\
\text { (SAW)berupaprototype sistem }\end{array}$ \\
\hline Pembuatan Laporan & Laporan Penelitian \\
\hline
\end{tabular}

Gambar 1. Alur Penelitian 
Berdasarkan alur penelitian yang telah digambarkan diatas maka dapat diuraikan pembahasan masing masing tahap dalam penlitian adalah sebagai berikut :

a. Perumusan Masalah

Dalam tahap ini, peneliti merumuskan yang akan diteliti. Dengan adanya perumusan masalah, maka penelitian akan menjadi jelas dan terarah.

b. Studi Literatur

Pada tahap ini penulis melakukan apa yang disebut dengan kajian pustaka yaitu mempelajari sumber kepustakaan berupa buku-buku referensi, artikel pada situs-situs yang relevan mengenai penelitian. Dengan tujuannya adalah untuk mendapatkan pemahaman teori dan konsep tentang masalah yang diteliti. Yang nantinya dapat digunakan oleh penulis dalam perancangan sistem dan pembuatan laporan.

c. Pengumpulan Data

Untuk mendapatkan informasi dan data - data yang tepat penulis menggunakan beberapa teknik pengumpulan data sebagai berikut :

1. Pengamatan (Observation)

Dalam hal ini yang akan dilakukan adalah melihat serta mempelajari permasalahan yang ada dilapangan yang erat kaitannya dengan objek yang diteliti yaitu informasi tentang penerima banuan PKH pada lokasi objek yang di teliti.

2. Wawancara (Interview)

Dalam hal ini, peneliti melakukan wawancara (interview) secara langsung dengan pihak yang terkait guna memperoleh data yang relevan dengan penelitian.

d. Analisis Sistem

Setelah pengumpulan data selesai, selanjutnya dilakukan analisis terhadap sistem dengan bantuan datadata yang ada. Hal ini bertujuan melakukan pengelompokkan terhadap data yang telah dikumpulkan dan diolah sehingga memudahkan penulis dalam melakukan analisis sistem. Analisis yang akan dilakukan dalam penelitian ini adalah menentukan penerima bantuan PKH berdasarkan bobot penilaian dan kriteria yang sudah ditentukan menggunakan metode Simple Additive Weighting (SAW).

e. Perancangan Sistem

Perancangan sistem dalam penelitian ini menghasilkan output berupa prototype.

f. Pembuatan Laporan

Pada tahap ini, penulis membuat laporan dari penelitian yang berisikan laporan penelitian terhadap masalah-masalah dan solusi yang ada pada objek yang diteliti oleh penulis.

\section{Hasil dan Pembahasan}

Hasil dan pembahasan akan diuraikan sebagai berikut :

4.1 Hasil

Hasil analisis terhadap sistem yang sedang berjalan untuk mengatasi permasalahan yang ada maka diperlukan sistem pendukung keputusan yang dapat membantu pengambilan keputusan penerima bantuan PKH sesuai kriteria.

Dan salah satunya melalui penentuan kriteria untuk mendapatkan PKH secara terukur dengan mengunakan metode yang digunakan pada sistem pendukung keputusan Simple Additive Weighting (SAW). Juga akan dirancang sebuah prototype sistem aplikasi yang berfungsi antar muka dengan user dalam melakukan penentuan calon penerima bantuan PKH. Dalam metode Simple Additive Weighting (SAW), matrik keputusan atau yang dikenal dengan rating kinerja merupakan kondisi yang mempresentasikan kecocokan antara alternatife terhadap setiap kriteria dan merupakan unsur penting dalam menyelesaikan permasalahan pada sistem penunjang keputusan dengan metode $S A W$.

Setelah melakukan analisa dari mengambil hasil wawancara, observasi dan penyebaran instrument, maka kebutuhan sistem pada Sistem Pendukung Keputusan Penerima Bantuan Program Keluarga Harapan di Dinas Sosisal Kependudukan dan Pencatatan Sipil Provinsi Jambi diharapkan melahirkan beberapa fitur-fitur dalam menentukan kebutuhan sistem untuk membangun sistem pendukung keputusan. Adapun fitur yang di rancang dalam kebutuhan sistem penunjang keputusan tersebut diantaranya :

a) Tampilan aplikasi berbasis desktop

b) Fitur yang akan di rancang yaitu adanya tombol proses perhitungan penentuan penerima bantuan secara otomatis dengan menggunakan metode Fuzzy Logic SAW sehingga tidak perlu lagi menghitung secara manual.

c) Fitur yang akan di rancang yaitu halaman untuk menginput kriteria penilaian yang dimana nantinya bisa menambah, merubah maupun menghapus kriteria yang ada. 
d) Terdapat Fitur Laporan untuk mencetak total peserta, peserta layak dan peserta tidak layak.

Untuk menentukan matriks keputusan dan bobot keputusan, maka pada penelitian ini penulis dapatkan dari hasil pengisian instrumen terhadap 104 orang responden yang merupakan data masyarakat miskin calon penerima PKH yang ada di Kecamatan Pasar Jambi Kota Jambi pada tabel dibawah ini dapat dilihat data responden :

Tabel 1. Data Responden

\begin{tabular}{|l|l|l|l|}
\hline NO & NAMA & KELURAHAN & PEKERJAAN \\
\hline 1 & Ernawati & Pasar Jambi & Ibu Rumah Tangga \\
\hline 2 & Fatimah & Orang Kayo Hitam & Ibu Rumah Tangga \\
\hline 3 & Rodiya & Orang Kayo Hitam & Ibu Rumah Tangga \\
\hline$\ldots$. & $\ldots$ dst & $\ldots$ dst & ..dst \\
\hline 104 & Syarifah Yuni & Sungai Asam & Ibu Rumah Tangga \\
\hline
\end{tabular}

Dalam metode $S A W$ terdapat beberapa kriteria yang dibutuhkan untuk menentukan kelayakan penerima bantuan PKH di Dinas Sosdukcapil Provinsi Jambi. Adapun masing-masing kriteria tersebut akan di tentukan bobot prioritas berdasarkan hasil kuisioner terhadap 104 responden. Adapun kriteria sebagai berikut :

Tabel 2. Kode Kriteria dan Ketentuan Kriteria

\begin{tabular}{|c|l|}
\hline Kode Kriteria & Ketentuan Kriteria \\
\hline C1 & Anak SD \\
\hline C2 & Anak SMP \\
\hline C3 4 & Anak SMA \\
\hline C5 & Bumil/Nifas/Balita \\
\hline C6 & Lanjut Usia $>70$ \\
\hline C7 & Disabilitas Berat \\
\hline C8 & Jenis Dinding Rumah \\
\hline C 10 & Luas Bangunan \\
\hline C10 & Pekerjaan \\
\hline
\end{tabular}

Dari masing-masing kriteria tersebut akan di tentukan nilai dari tiap bobot. Pada bobot terdiri dari lima bilangan fuzzy, yaitu :
a. ST = Sangat Tinggi
b. $\mathrm{T}=$ Tinggi
c. $\mathrm{C} \quad=$ Cukup
d. $\mathrm{R}=$ Rendah
e. SR = Sangat Rendah

Dari uraian diatas, maka bilangan-bilangan fuzzy dapat di konversikan ke bilangan crips. Untuk lebih jelas data bobot dibentuk tabel di bawah ini :

Tabel 3. Nilai Bobot

\begin{tabular}{|l|c|}
\hline Bilangan Fuzzy & Nilai \\
\hline Sangat Tinggi & 10 \\
\hline Tinggi & 7,5 \\
\hline Cukup & 5 \\
\hline Rendah & 2,5 \\
\hline SangatRendah & 0 \\
\hline
\end{tabular}

Untuk alternative (Ai) merupakan data masyarakat miskin seperti pada tabel berikut : 
Tabel 4. Alternatif

\begin{tabular}{|c|l|c|}
\hline No & Alternatif & Kode Alternatif \\
\hline 1. & Ernawati & A1 \\
\hline 2. & Fatimah & A2 \\
\hline 3. & Rodiya & A3 \\
\hline 4. & $\ldots . . n$ & A..n \\
\hline
\end{tabular}

\subsection{Pembahasan}

Berdasarkan langkah-langkah untuk melakukan penentuan penerima bantuan PKH di Dinas Sosdukcapil Provinsi Jambi dengan menggunakan metode Simple Additive Weighting (SAW), maka yang harus dilakukan yaitu dengan memberikan nilai setiap alternatif (Ai) pada setiap kriteria (Ci) yang sudah ditentukan.

a. Kriteria Anak SD ( $\mathrm{C}_{1}$ )

Tabel 5. Kriteria Anak $S D\left(C_{1}\right)$

\begin{tabular}{|l|l|l|}
\hline Anak SD & Bilangan Fuzzy & Nilai \\
\hline Ya & Sangat Tinggi & 10 \\
\hline Tidak & Rendah & 0 \\
\hline
\end{tabular}

b. Kriteria Anak SMP ( C2 )

Tabel 6. Kriteria Anak SMP $\left(C_{2}\right)$

\begin{tabular}{|l|l|l|}
\hline Anak SMP & Bilangan Fuzzy & Nilai \\
\hline Ya & Sangat Tinggi & 10 \\
\hline Tidak & Rendah & 0 \\
\hline
\end{tabular}

c. Kriteria Anak SMA ( C3)

Tabel 7. Kriteria Anak SMA $\left(C_{3}\right)$

\begin{tabular}{|l|l|l|}
\hline Anak SMA & Bilangan Fuzzy & Nilai \\
\hline Ya & Sangat Tinggi & 10 \\
\hline Tidak & Rendah & 0 \\
\hline
\end{tabular}

d. Kriteria Bumil/Nifas/Balita ( C4 )

Tabel 8. Kriteria Bumil/Nifas/Balita $\left(C_{4}\right)$

\begin{tabular}{|l|l|l|}
\hline Bumil/Nifas/Balita & Bilangan Fuzzy & Nilai \\
\hline Ya & Sangat Tinggi & 10 \\
\hline Tidak & Rendah & 0 \\
\hline
\end{tabular}

e. Kriteria Lanjut Usia > 70 Tahun ( C5)

Tabel 9. Kriteria Lanjut Usia > 70 Tahun $\left(C_{5}\right)$

\begin{tabular}{|l|l|l|}
\hline Lanjut Usia $>70$ & Bilangan Fuzzy & Nilai \\
\hline Ya & Sangat Tinggi & 10 \\
\hline Tidak & Rendah & 0 \\
\hline
\end{tabular}


f. Kriteria Disabilitas Berat $\left(\mathrm{C}_{6}\right)$

Tabel 10. Kriteria Disabilitas Berat (C6)

\begin{tabular}{|l|l|l|}
\hline Disabilitas Berat & Bilangan Fuzzy & Nilai \\
\hline Ya & Sangat Tinggi & 10 \\
\hline Tidak & Rendah & 0 \\
\hline
\end{tabular}

g. Kriteria Jenis Dinding Rumah $\left(\mathrm{C}_{7}\right)$

Tabel 11. Tabel Kriteria Jenis Dinding Rumah $\left(C_{7}\right)$

\begin{tabular}{|l|l|l|}
\hline Jenis Dinding Rumah & Bilangan Fuzzy & Nilai \\
\hline Bambu & Sangat Tinggi & 10 \\
\hline Papan/Kayu & Tinggi & 7,5 \\
\hline Tembok berkualitas rendah & Cukup & 5 \\
\hline Tembok berkualitas tinggi & Sangat Rendah & 0 \\
\hline
\end{tabular}

h. Kriteria Luas Bangunan $\left(\mathrm{C}_{8}\right)$

Tabel 12. Kriteria Luas Bangunan $\left(C_{8}\right)$

\begin{tabular}{|l|l|l|}
\hline Luas Bangunan $\left(\mathrm{m}^{2}\right)$ & Bilangan Fuzzy & Nilai \\
\hline $0 \mathrm{~m}^{2}-20 \mathrm{~m}^{2}$ & Sangat Tinggi & 10 \\
\hline $21 \mathrm{~m}^{2}-50 \mathrm{~m}^{2}$ & Tinggi & 7,5 \\
\hline $51 \mathrm{~m}^{2}-100 \mathrm{~m}^{2}$ & Cukup & 5 \\
\hline $101 \mathrm{~m}^{2}-500 \mathrm{~m}^{2}$ & Rendah & 2,5 \\
\hline$>500 \mathrm{~m}^{2}$ & Sangat Rendah & 0 \\
\hline
\end{tabular}

i . Kriteria Pekerjaan $\left(\mathrm{C}_{9}\right)$

Tabel 13. Kriteria Pekerjaan $\left(C_{9}\right)$

\begin{tabular}{|l|l|l|}
\hline Pekerjaan & Bilangan Fuzzy & Nilai \\
\hline Ibu Rumah Tangga & Sangat Tinggi & 10 \\
\hline Pedagang & Tinggi & 7,5 \\
\hline Karyawan Swasta & Rendah & 2,5 \\
\hline PNS & Sangat Rendah & 0 \\
\hline
\end{tabular}

j. Kriteria Penghasilan $\left(\mathrm{C}_{10}\right)$

Tabel 14. Kriteria Penghasilan $\left(C_{10}\right)$

\begin{tabular}{|l|l|l|}
\hline Penghasilan & Bilangan Fuzzy & Nilai \\
\hline$<2.000 .000$ & Sangat Tinggi & 10 \\
\hline 2.000 .000 s.d 3.000.000 & Cukup & 5 \\
\hline$>3.000 .000$ & Sangat Rendah & 0 \\
\hline
\end{tabular}

Nilai alternative setiap kriteria di dapat dari penyebaran quisioner kepada 104 masyarakat miskin sebagai responden dan dimasukkan kedalam tabel seperti pada tabel dibawah ini: 
Tabel 15. Nilai Alternatif di setiap Kriteria

\begin{tabular}{|c|c|c|c|c|c|c|c|c|c|c|c|}
\hline \multirow{2}{*}{ Kode } & \multirow{2}{*}{ Alternatif } & \multicolumn{10}{|c|}{ Kriteria } \\
\hline & & $\mathrm{C} 1$ & $\mathrm{C} 2$ & $\mathrm{C} 3$ & $\mathrm{C} 4$ & $\mathrm{C} 5$ & C6 & $\mathrm{C} 7$ & $\mathrm{C} 8$ & C9 & $\mathrm{C} 10$ \\
\hline A1 & Ernawati & 10 & 0 & 0 & 10 & 0 & 0 & 5 & 7,5 & 10 & 10 \\
\hline $\mathrm{A} 2$ & Fatimah & 0 & 0 & 0 & 0 & 0 & 0 & 5 & 7,5 & 10 & 10 \\
\hline A3 & Rodiya & 0 & 10 & 0 & 0 & 0 & 0 & 7,5 & 7,5 & 10 & 10 \\
\hline ...dst & $\ldots$ dst & ...dst & ...dst & ...dst & $\ldots \mathrm{dst}$ & $\ldots \mathrm{dst}$ & ...dst & ...dst & ...dst & $\ldots \mathrm{dst}$ & . dst \\
\hline A104 & Syarifah Yuni & 0 & 10 & 0 & 0 & 0 & 0 & 7,5 & 7,5 & 10 & 5 \\
\hline
\end{tabular}

Kemudian Tabel Rating Kecocokan di ubah kedalam matriks keputusan X, seperti pada gambar berikut ini :

$$
\mathbf{X}=\left\{\begin{array}{llllllllll}
10 & 0 & 0 & 10 & 0 & 0 & 5 & 7,5 & 10 & 10 \\
0 & 0 & 0 & 0 & 0 & 0 & 5 & 7,5 & 10 & 10 \\
0 & 10 & 0 & 0 & 0 & 0 & 7,5 & 7,5 & 10 & 10 \\
\ldots \text { dst } & \ldots \text { dst } & \ldots \text { dst } & \ldots \text { dst } & \ldots \text { dst } & \ldots \text { dst } & \text { dst } & \text { dst } & \text { dst } & \text { Dst } \\
0 & 10 & 0 & 0 & 0 & 0 & 7,5 & 7,5 & 10 & 5
\end{array}\right\}
$$

Gambar 2. Matriks Keputusan X

Perhitungan hasil calon penerima bantuan PKH dilakukan sebagai berikut:

A. Rating Kecocokan Alternative Setiap Kriteria

Untuk menentukan usulan prioritas calon penerima bantuan PKH menggunakan Model Fuzzy Multiple Attribute Descision Making (FMADM) dengan metode Simple Additive Weighting (SAW) dilakukan pemberian nilai setiap alternatif $(\mathrm{Ai})$ pada setiap kriteria $(\mathrm{Cj})$ yang sudah di tentukan.

B. Memberikan Nilai Bobot (W)

Nilai bobot untuk tiap kriteria penulis dapatkan dari hasil wawancara dengan Kepala Dinas , nilai bobot dapat dilihat dalam tabel 16 dibawah ini :

Tabel 16. Bobot untuk prioritas

\begin{tabular}{|l|l|l|}
\hline Kriteria & Bobot & Nilai \\
\hline C1 & Sangat Tinggi & 10 \\
\hline C2 & Sangat Tinggi & 10 \\
\hline C3 & Sangat Tinggi & 10 \\
\hline C4 & Sangat Tinggi & 10 \\
\hline C5 & Sangat Tinggi & 10 \\
\hline C6 & Sangat Tinggi & 10 \\
\hline C7 & Tinggi & 7,5 \\
\hline C8 & Cukup & 5 \\
\hline C9 & Cukup & 5 \\
\hline C10 & Cukup & 5 \\
\hline
\end{tabular}

Sehingga diperoleh vector bobot $(\mathrm{W})$ dengan data :

$\mathrm{W}=(10 ; 10 ; 10 ; 10 ; 10 ; 10 ; 7,5 ; 5 ; 5 ; 5)$ 
Normalisasi Matriks Keputusan X ke persamaan menggunakan rumus di berikut ini:

$$
r_{i j}= \begin{cases}\frac{X_{i j}}{\operatorname{Max} X_{i j}} & \text { Jikaj adalah atribut keuntungan (Benefit) } \\ \frac{\operatorname{Min}_{i j} X_{i j}}{X_{i j}} & \text { Jika jadalah atribut biaya (Cost) }\end{cases}
$$

Keterangan :

Gambar 3. Rumus Normalissai Matriks Keputusan

$$
\begin{array}{ll}
{ }_{\mathrm{rij}} & =\text { Nilai rating kinerja ternomalisasi } \\
\mathrm{X}_{\mathrm{ij}} & =\text { Nilai atribut yang dimiliki dari setiap kriteria }
\end{array}
$$

Max $X_{\mathrm{ij}}=$ Nilai terbesar dari setiap kriteria $i$

Min $\mathrm{X}_{\mathrm{ij}}=$ Nilai terkecil dari setiap kriteria $i$

\section{Kesimpulan dan Saran}

Kesimpulan dan saran yang dapat diambil pada pembahasan mengenai analisis Sistem Pendukung Keputusan dalam penentuan penerima bantuan Program Keluarga Harapan (PKH) di Dinas Sosial Kependudukan dan Pencatatan Sipil Provinsi Jambi adalah sebagai berikut :

\subsection{Kesimpulan}

1. Sistem yang dirancang untuk membantu pihak Dinas Sosial Kependudukan dan Pencatatan Sipil Provinsi Jambi dalam menentukan keluarga miskin layak atau tidak layak dalam menerima bantuan Program Keluarga Harapan (PKH)

2. Sistem dirancang telah menghasilkan fitur seperti fitur perhitungan yang menggunakanmetode Fuzzy logic Simple Additive Weighting, sehingga memudahkan pihak dinas dalam menentukan kelayakan keluarga miskin dalam mendapat bantuan PKH. Kemudian fitur Kriteria, yang dimana fitur kriteria ini berfungsi untuk menambah kriteria penilaian dalam menentukan kelayakan keluarga miskin dalam mendapat bantuan. Selanjutnya fitur Laporan,fiturlaporan ini adalah hasil output dari perhitungan kelayakan keluarga miskin dalam mendapat bantuan

3. Karena sistem ini telah dirancang menggunakan metode Fuzzy logic Simple Additive Weighting, maka dapat disimpulkan bahwa penerapan metode ini telah memberikan hasil yang bisa digunakan untuk menentukan kelayakan keluarga miskin dalam mendapatkanbantuan. Hasil inilah yang akan digunakan oleh Dinas Sosial Kependudukan dan Pencatatan Sipil Provinsi Jambi untuk menentukan kelayakan keluarga miskin dalam mendapatkan bantuan PKH.

\subsection{Saran}

1. Sistem yang dibangun ini masih sebatas prototype, sehingga perlu dikembangkan lebih lanjut sehingga terwujud sistem pendukung keputusan yang lengkap dan secara riil dapat diimplementasikan untuk memberikan hasil yang lebih komprehensif untuk menentukan keluarga miskin dalam mendapatkan bantuan PKH.

2. Karena sistim yang akan dibangun berhubungan dengan data kemiskinan maka perlu dibuat keamanan sistem yang baik untuk menjaga keamanan data dari gangguan.

\section{Daftar Rujukan}

[1] Dennis, Alan; Wixom, Haley Barbara: \& M.Roth, Roberta., 2010. Systems Analysis and Design.Fourth Edition. United States of America : John Wiley \& Sons, Inc.

[2] Desriyanti; Muslim, Munirah.2015. Sistem Penunjang Keputusan Pemberian Bantuan Masyarakat Miskin Menggunakan Metode Simple Additive Weighting (SAW). Prosiding SENATEK 2015 Fakultas Teknik, Universitas Muhammadiyah Purwokerto.

[3] Kendall, E. Kenneth; \& Kendall, E. Julie., 2011.Systems Analysis and Design.Eighth Edition. United States of America : Pearson Education Inc

[4] Kenneth E. Kendall dan Julie E. Kendall, 2010, Analisa dan Perancangn Sistem. Jakarta : PT Indeks.

[5] Laudon, Kenneth C; \& Laudon, Jane P. 2012. Management Information Systems (Managing The Digital Firm). Twelfth Edition. United States of America : Pearson Education Inc 
[6] Lestari, Uning; Targiono,Muhammad. 2017. Sistem Pendukung Keputusan Klasifikasi Keluarga Miskin Menggunakan Metode Simple Additve Weighting (SAW) Sebagai Acuan Penerima Bantuan Dana Pemerintah (Studi Kasus: Pemerintah Desa Taman Martani, Sleman). Jurnal Technology Acceptance Model, Volume 8, Nomor 1, Yogyakarta :Institut Sains \& Teknologi AKPRIND.

[7] Sukerti, Ni Kadek. 2014. Sistem Penunjang Keputusan Penerima Bantuan Desa Di Kecamatan Klungkung Dengan Metode SAW. Jurnal Informatika. Volume 14, Nomor 1. Bali: Sekolah Tinggi Ilmu Komputer Bali.

[8] Turban, E., Aronson; \& J.E Liang, T.P.2007.Decision Support System and Intelligent System. New Jersey : Pearson Education Inc.

[9] Yogiyanto Hartono, 2005, Analisis dan Desain Informasi : Pendekatan Terstruktur Teori dan Praktek Aplikasi Bisnis. Yogyakarta : Andi.

[10] Yulianto, Ardian Agung dkk. 2009. Analisis dan Desain Sistim Informasi .Bandung : Politeknik Telkom [11] Kementerian Sosial RI.2016. Buku Pedoman Umum Program Keluarga Harapan. 